\title{
SUFI HEALING COMMODIFICATION THROUGHOUT EAST JAVA URBAN ENVIRONMENTS
}

\author{
M. Syamsu[Huda \\ UIN Sunan Ampel Surabaya \\ Email: msyamsulhud@gmail.com
}

\begin{abstract}
This article examines the shifting of the functions and motives of Sufi healing from the pesantren tradition, in which the main actor is the healer kiai who prioritizes community service and healing as part of the da'wah, changing to capital motives in conducting healing traditions in Islam. The research process used participatory observation method in clinical settings to examine Sufi healing practices and interview therapists and patients who use Sufi healing services, as well as comparative-historical methods in studying the ontology and epistemology of healing. The findings of this study include: first, Sufi healing contains elements of bayani, irfani, and finally bil kasbi. Yet, in practice it takes the irfani as the most common method, especially through the method of prayer, $z i k r$, and prayer. Second, the integration built by Islamic therapists is done by combining medical method in the area of marketing share and psycho-sufism to build patient confidence. Third, this role is more than Sufi healing prioritizing the practice of religious capitalization, namely identifying medical treatment clinics in the form of Sufi healing for economic purposes.
\end{abstract}

Artikel ini mengkaji pergeseran fungsi dan motif penyembuhan sufi dari tradisi pesantren yang aktor utamanya kiai tabib yang mengutamakan pengabdian kepada kesehatan dan penyembuhan masyarakat sebagai bagian dari dakwah, berubah ke motif kapital tradisi penyembuhan dalam Islam. Dalam proses penelitian menggunakan metode observasi partisipatif ke tempat klinik yang membuka praktek penyembuhan sufi dan mewawancarai terapis dan pasien 
yang menggunakan jasa penyembuhan sufi, serta menggunakan metode historis komparatif dalam menelaah ontologi dan epistemologi penyembuhan. Adapun temuan penelitian ini antara lain pertama, penyembuhan sufi memuat unsur bayani, irfani, dan terakhir bil kasbi. Namun dalam prakteknya cara irfani menjadi metode yang paling umum dilakukan, khususnya melalui metode do'a, zikir, dan salat. Kedua, integrasi yang dibangun para terapis islami adalah dengan cara memadukan antara cara medis pada wilayah pemasaran dan psiko sufistik untuk membangun keyakinan para pasien. Ketiga, peran ini lebih dari sufi healing yang mengutamakan praktik kapitalisasi agama, yakni mengidentifikasi klinik jasa pengobatan dalam bentuk penyembuhan sufi demi tujuan ekonomis.

Keywords: commodification; kiai-tabib; sufi healing

\section{Introduction}

Healing always deals with disease. In the history of mankind, there are numbers of healing methods used by people in the world; four methods become the most popular ones. First, modern healing is generally based on modern medical science. Second, traditional healing is the one most use old and conventional ways normally implemented by old societies such as acupuncture, massage, the use of herbs, and so forth. Third, spiritual healing is based on spiritual activities such as yoga, magnetism, hypnotism, beliefs, and breathing exercises (Sha, n.d.). Islamic aspect claims spiritual healing which is also known as Sufi healing.

Sufi healing refers to the healing method through Sufi's spiritual power (Hermansen, 2005). This particular healing method is distinctly different from other healing methods; modern healing, for instance. Modern healing methods detect medical as well as non-medical symptoms of a disease. Afterward, scientific investigations such as searching for the significant causes to reduce and even fight the symptoms of the disease. On the contrary, the spiritual power healing method does not deal with the causes of disease. No investigation mechanism through medical science is needed. Yet, it focuses more on communication with the creator of diseases, establishing transcendental relations with the essence of life and the Highest: God (Trimingham, 1998).

Although Sufi healing is based on mystical power, it does not deal with mystical healing beyond spirituality such as shamanism practice. Most traditional communities rely on shaman or witches considered to involve Jinn's and other spirits' assistance for healing. This particular method is distinctly 
different from that of Sufi healing as sufism is based on a transcendental way free from Jin's and other spirits' involvement, yet primarily relies on the spiritual dimension dealing with divine guidance (Trimingham, 1998).

In the perspective of Islam, healing through sufism is basically under the guidance of the Holy Qur'an as well as the hadith of Rasulullah Muhammad SAW (Rabbani \& Wirasubrata, 2004). Islam introduces at least four ways of healing: praying and prayer service, use of traditional herbs, special divine practice through specific tools mostly implemented in pesantren (Islamic boarding schools). Pesantren is known as an Islamic educational institution of which curriculum provides sufism practice.

Yet, further through its development, especially in the modern era, Sufi healing is not only implemented in pesantren but also conducted in some urban areas. In the province of East Java, statistics show a large number of Islamic therapies with each creativity. In Surabaya alone, over 65 therapists actively do health promotions through the advertisement of televisions, Radios, Websites, newspapers, and brochures (Nurani, June 2019). In Sidoarjo, a wide range of therapists actively carry out their practical healings in each village (interview with Sutrisno, 2012). Interestingly enough, though implemented in modern life throughout urban areas, both use similar techniques of Sufi healing normally implemented by kiai (moslem's leaders) in pesantren.

Hence, massively rapid emergence of Sufi healing (Mitha, 2019) has become a social phenomenon on which intensive study needs to be undertaken. Moreover, the practice of Sufi healing deals with complex social dimensions. In other words, the phenomenon of Sufi healing is closely related to social features such as economy, sociology, or even religious capitalism. Thus, critical questions on Sufi healing need to be addressed:

First, how do moslem therapists integrate sufistic values in their therapy techniques? Sufism represents moslem spiritual leaders such as kiai. Whereas, Sufi healing in urban areas does not necessarily represent Sufism as it should be. Thus, the phenomenon of Sufi healing refers to Islam commodification, and spiritual symbols based on transcendental power was aimed to attract public attention. George Luckas, in the theory of social Neo Marxian put this particular phenomenon as religious reification.

Second, based on the Islamic principle, what kinds of Sufi healing spiritual values are adopted by moslem therapists? Third, why do moslem therapists prefer sufistic values as a reference for healing technique and method to other 
healing values which are scientifically more effective and both methodically and empirically proven such as psychological and medical therapies, etcetera?

From the above-mentioned questions, this study suggested a hypothesis that therapies for healing using sufistic values guarantee more ethical and spiritual quality psychologically acceptable to obtain a positive effect for patients though the healing effectiveness has not yet been directly proven when compared to medical therapy. Also, sufictic medical practice merely works as a branding campaign. Through religious symbols represented in Sufi healing, prospective economic profits could be brought in. However, to examine the hypothesis, an in-depth study needs to be conducted specifically on Sufi healing phenomenon as well as any impact estimated.

\section{Sufi Healing: Conceptual Perspective}

As Sufi healing comprises two words: Sufi and healing, these two words need to be separately analyzed for comprehensive understanding. Sufi is a popular word normally used in Tasawuf (Islamic philosophy) as it refers to human's self-value (objectification) through the process of self-internalization in the study of tasawuf.

According to the unabridged dictionary of Bahasa Indonesia, Sufi means the master of ilmu suluk (the master of magical power) (n), the master of Tasawuf (philosophy). In addition, another reference suggested that Sufi comes from Suf (a kind of wool) referred to the lifestyle in which the prophet Muhammad's best friends wore woolen garments (Rabbani \& Wirasubrata, 2004; Rubaidi, 2019). In the past, especially in the era of Hasan Basri, one of Ali's students (Ali was Prophet Muhammad's cousin who happened to be his son-in-law) suggested that Ali bumped into seventy people of the prophet's best friends wearing woolen garments and participated in the war of Badar. Furthermore, two beloved friends of prophet Muhammad are also known as khalifahs, Abu Bakar and Umar with other best friends called Ashab-i-Shuffah also wore woolen garments (Rabbani \& Wirasubrata, 2004).

Tasawuf has been well-known since the prophecy era, though it was only implemented through attitudes and practical activities. The term of Tasawuf firstly appeared in the world of Islam in the 3rd century Hijriah (Islamic calendar). However, its comprehensive definition remains debatable, especially among academicians. Some people assured that tasawuf refers to Sufah; woolen cloth. Whereas, another reference claimed that tasawuf refers to 'Ibnu Shauf'; a good public figure well known before Islam was introduced. Ibnu Shauf 
often stood up in front of Ka'bah to devote his time to worship the Lord of the 'Alamin (mankind, Jinns, and all that exist). Whereas, another version suggested that tasawuf comes from 'sofia'-a Greek terminology referring to Sofis which means hikmah (guidance) or philosophy (Djaelani, 1996).

Furthermore, in terms of terminology, Zakaria al-Anshari in Amin Syukur (2012) defined tasawuf as a set of knowledge through which the soul purification, more positive attitude, and soul and physical development to achieve eternal happiness will be reached (Syukur, 2012). It implies that, in practice, tasawuf does not only refer to religious values about the core of life, but it also refers to values of life both in terms of physic, soul, and even social relationship.

Whereas, Abu Hasan al-Syadzili suggested that tasawuf refers to attempts for mental self-training through which persistence and consistency for better worship and upholding the laws of God. In line with Abu Hasan al-Syadzili, Ibnu Ujaibah also referred tasawuf to set of religious knowledge to lead human beings to approach God and get rid of various inner badness and disgraceful behavior/ conduct (Isa, 2005). In short, tasawuf basically refers to human's physical and inner purification to eventually approach God the creator. Tasawuf / philosophical conduct come in zikir (religious recitatives), salah (prayer), fasting, taubat (all goodness referring to worship and sincerity only for God the Almighty).

Healing is an English word; to heal means to make things well again. According to English linguistics, the word heal refers to depicting completeness, perfecting; health recovery; free of any disease. Another meaning of heal is an attempt at reconciliation eventually leading to unification and/or recovery. Besides, it means self-freedom of various negative traits, negative behavior, and negative conduct referring to the trait of dehumanism; purifying as well as getting rid of various badness. It also means as a physical effect due to certain medications (O'riordan, 2002).

Thus, from the above-mentioned four definitions healing has a comprehensive meaning. The concept of healing does not necessarily refer to physical healing, but it may also refer to healing for a mental disorder, inappropriate behavior, negative traits. It can also refer to attempts to strengthen social integration to deal with various threats of conflict and disintegration.

Thus, sufi healing refers to a healing instrument, a cure for a disease based on the approach and method of tasawuf. According to the approach of tasawuf, some Islamic activities such as zikir (recitative), prayer, fasting, Qur'an 
recital belong to spiritual activities providing peacefulness, producing positive energy for a healthy soul. Sufi healing convinced that health should refer to mental health obtained from self-spiritual fulfillment. For the sake of spiritual balance, one should prevent themselves from inappropriate behavior, get rid of anything against religious values, attempt to approach God the almighty. Sins in the perspective of is a partition hindering the human-God relationship and which can even lower one's quality of life and will attract mental badness.

\section{Sufi as Healing: Theoretical Review.}

According to some western references, sufism is considered to be part of Islamic mysticism as it refers to self-experience through the path of divine love in which God award human beings with life including ecstatic experience, a situation referring to mystical experience (Wilcox, 2007). Moslem scholars such as Fazlur Rahman, Ibn Taymiah, and Ibn Qayyim al-Jauziah confirmed that sufi was always referred to tasawuf, which did not only deal with Islamic ethic and esthetic but it was also related to soul, spirit, and intuition (Wilcox, 2007). Sufi is the most honorable guru in Islam with a single responsibility to keep and proceed with in-depth knowledge implied in the Holy Qur'an. To most sufi gurus, their life purposes are to take care of life management awarded by God on earth. The service provided by Sufi gurus to mankind is profoundly important, as taught by God through His Beneficent and Merciful attributes.

In the light of the Islamic mystical perspective, diseases created by God come in three categories; disease as assessment, disease dealing with behavior in the past, and disease as a preliminary examination before death. Two types of diseases such as disease as assessment and that with the background in the past are curable. Whereas, a disease leading to death obviously cannot be cured though through medical approach or under spiritual power.

Sufi healing is a therapy implemented for ages. Sufi healing is based on faith that all diseases intentionally created by God, and only through His blessings, all disease can be cured. God (Allah) is the only One who can recover one's health after severe disease. Hence, virus, bacteria, amoeba, fungi, and even non-medical cause of the particular disease (magic, santet (Indonesian magic), etc) are all the creations of God, and can surely be cured/overcome. From the perspective of tasawuf, the most influential factor of disease suffered by mankind is the absence of spiritual values. In other words, mankind keeps a long distance from God. They prefer hedonic, pragmatic, and individualistic lifestyle, and live their lives without religious values. Without spiritual values, 
human will live with unstable mental, mental disorder, unpeaceful heart, stress, et cetera. Hence, sufism comes with the healing therapy for a wide range of unstable conditions based on a positive approach to God the Creator. Any disease which appears due to lack of spiritual values mostly cannot be cured especially with any method beyond the patient, even if modern medical healing technique was carried out. Disease coming from inside can only be cured through spiritual method or sufistic healing (Syukur, 2012).

Tasawuf work ethic relies on spiritual aspects that encourage humane behavior such as upholding moral values, positive attitudes, and behavior. Mystical feelings and spiritual experience lit in the soul will result in kindness and purify the soul. Thus, peacefulness, finest mind, the beauty of feeling will eventually emerge. Once spirituality grows, the soul remains stable, and all kinds of anxiety and confusion. Moreover, the neuroscientific study suggested that the spiritual aspect plays a pivotal role and has an essential function in the life of mankind. One's character was built up based on the spiritual aspect. Through the spiritual aspect, one can find their true color, and can also acquire their significance through their every single action (Pasiak, 2007). Neuroscientists suggested the spiritual aspect as lobus temporalis also known as God spot. Thus, in this particular context, tasawuf known to deal with spirituality can be part of healing instruments that rely on the use of spiritual power and potentials to the full which lie in lobus temporalis.

\section{Islamic Ritual Activities in Sufi Healing}

Tasawuf is part of knowledge in which the goodness and badness of human's souls can be identified, exhibit the cleanliness of disgracefulness followed by an excellent character coming in, praying and approaching God for his mercy and getting rid of God's prohibition and denial going through His blessings (Jamil, 2004). Ways to achieve God's blessings are part of long spiritual struggles that take attributes of sincerity, obedience, qona'ah (receiving things as they are), and readiness to live. Through such a life one should live with the internalization of divine values. Total worship to God will, in turn, lead to the highest position once our ego is left and only spirituality is embraced. It is, in the world of Sufi, known as the achievement of Fana al Fana or Baqa bi Allah (Rabbani, 2004). Both conditions directly deal with the inner situation, especially what concerns the heart. Some traits such as wara' (being careful with bad things), zuhd (getting rid of worldly concerns), șabr (patience), tawadhu' (humility), taqwa (obedience to God), tawakkal 
(receptiveness), ridha (sincerity), mahabbah (love), and ma'rifah (highest level of trait) are media to the highest level of spirituality known as maqamat and ahwal in tasawuf.

Maqam refers to total and the highest level of continuous worship to God, and result in more appropriate behavior as well as much better conduct. Whereas, Ahwal refers to whatever comes from inner attributes is the blessings of God for mankind. Thus, most traits of maqamat and ahwal are believed to play a pivotal role in the process of Sufi healing. Hence, Amin Masykuri) suggested some Islamic ritual activities normally used in Sufi healing such as taubat (searching for God's mercy), wara' (being careful with bad things), zuhud (getting rid of worldly concerns), șabar (patience), qana'ah (receptiveness of whatever destined for), ridha (sincerity or receptiveness of God's decision), tawakkal (receptiveness of God's assessment), moqarrabah (mentally approaching God), muraqabah (feeling to be observed by God), and ikhlas (sincerity) (Syukur, 2012).

Taubat or searching for God's mercy refers to feeling sorry and regret sins have been committed; confession of sins or crimes perpetrated and committed to rebuilding life, returning to God, and reembracing the right religion (Poerwadarminta, 1976). Thus, Taubat implies readiness, consciousness, regret for sins have been committed, totality in returning the 'straight way' (guidance of God).

Wara', according to the Indonesian unabridged dictionary, means showing obedience to God (Poerwadarminta, 1976). Besides, Pradityas, Hanafi, \& Zaduqisti (2015) defined wara' as attempts to get rid of syubhat (uncertain) things and to ignore things or activities not beneficial and even leave excessive things. Thus, wara' refers to the highest level of carefulness, sensibility, and getting rid of syubhat (uncertain) and haram (forbidden, unlawful) so that the goodness and purity of body and heart (feeling) are preventable.

Zuhud means not fond of worldly goods (possessions) such as food and drinks, clothes, house, wealth, and authority as all such things will surely be left behind after death (Thusi, 2003). The behavior of zuhud implies self-imposed exile from worldly excessive possessions, a hedonistic lifestyle, pragmatic way of life. Zuhud will lead to simple life and humility. Al-Qusyairi suggested that zuhud refers to leaving haram (unlawful, forbidden) things, as halal (lawful) things are God's blessings and mankind express their gratefulness by getting rid of worldly luxurious possessions and living the life with simple things and humility (Burij, n.d.). Whereas, al-Ghazali assured that zuhud means self-control 
especially from worldly influence with its non-permanent life and prioritizes eternal happiness in the hereafter (Al-Ghazali, n.d.).

Furthermore, Ibnu Qutadah suggested that zuhud refers to searching only for what is needed, maintaining dignity, develop the religion, and assist moslem community (Al-Aziz, 1998). Moreover, other moslem scholars claimed that zuhud means never disgracing worldly life not even gushing with high praise to it. Once a worldly fortune is approaching, not even happiness showed in, and once it is leaving, no need to express sadness (Al-Aziz, 1998). In short, the attitude of Zuhud refers to the priority of life in the hereafter which religion is in the top priority.

Sabar or patience refers to survival against adversities, controllable temper, perseverance, determination, calmness, unhurried (Poerwadarminta, 1976). Patience, according to, Dzunnun al-Mishry is getting rid of everything against Islamic laws, remaining calm in agony, and showing self-sufficiency in poverty (Syukur, 2012). Patience plays a pivotal role in the teachings of tasawuf, the most basic element in which one can accept and live the life without regrets. Patience refers to peacefulness, joviality, mental strength throughout life. Patience will surely result in peace in life, peacefulness, and positive energy.

Qana'ah, according to the Arabic-Indonesian dictionary Qana'ah means "happily accepting/receiving what is given to him/her (Ahnan, n.d.). Qana'ah means happy willing, while in terms of terminology it means accepting any condition happens to him/her without any burden especially when it is naturally wanted. In addition, Al-Azis in S. Noorhayati (2016) defined qonaah as the nature of happy willing with even very few gifts/blessings of God the Almighty. In shorts, qanaah generally refers to the attitude of self-readiness for life, always accept what lies ahead. It prevents mankind from insufficiency and all traits orientating towards greed in life. It always results in peace and inner happiness.

Ridha or willingness, according to the Indonesian unabridged dictionary, means willing, happy (Poerwadarminta, 1976). Ridla leads mankind to always accept whatever is destined for him. It leads to tolerance, no burden even if the reality of life goes against his / her will. Willingness and pleasure when undergoing whatever given by Lord will eventually lead to psychological growth and positive experiences, truth in thinking, divine will, and good deeds. Conversely, people of no ability to develop the nature of Ridla (willingness) will be easily filled with anger, chaotic thoughts, and mental anxiety. The way 
of life being taken will be filled with inner pressures, and endless feelings of inadequacy.

Tawakkal or surrender, according to the Indonesian unabridged dictionary, means surrender to God's will wholeheartedly. Tawakkal requires total surrender to God the Almighty (Poerwadarminta, 1976). God is the only goal and the only way to get back for all matters of life. It means to depend on God for every wish, affair, and way of life.

Just as Imam al-Ghazali put that tawakal is controlling heart to only deal with God as a Protector, as everything is not beyond His knowledge and power. Whereas, what beyond God cannot be dangerous and cannot provide benefits either (Al-Ghazali, 1995). Surrender (Resignation) denies worship and hopes in other than God because only God is the single substance that governs every human affair; from fortunes, life necessities, to the hereafter.

Muqarrabah or closeness to God or Lord; relating to ways mankind establishes intimacy with God (Syukur, 2012). In tasawuf, muqarrabah deals with relationship, closeness, and even intimacy of mankind and the Lord working as an indicator of the highest level of human spirituality. Muqarrabah also works as a medium by which humans establish communication with God. Religious rituals such as prayer establishment, fasting, conducting dzikir (reciting and remembering names of God), Holy Qur'an recital, and living the greatness of God are some methods of Muqarrabah implementation.

Muraqabah is knowledge and belief that God is always seeing, watching, and the only omniscient (As-Sarraj. 2002). Muraqabah is the belief that every behavior, action, even every beat of the heart is always under the supervision and sense of God. Nothing is missing from the God Himself as God the only Omniscient Essence of everything that exists in the universe, even in the smallest natural entity of dust. With the character of muraqabah someone will always be introspective, self-awareness comes in to do good deeds and ignore evil treatments. Thus, body and mentality will be protected from bad and despicable attitude.

Ikhlas or sincerity is a zone located in the heart in the form of quantum in which happiness seekers and science lovers are missing it. This zone contains all necessities of human life, like water resources needed by the universe (Sentanu, 2008). Ikhlas teaches mankind to accept life certainty with patience and grace. In Sufism, sincerity is the fundamental element underlying other traits. Sincerity can be the most important part of human mentality for goodness. Sincerity can also encourage mankind to be grateful for the fact 
of life lies ahead. Peace in life always comes in that no more reasons to stand against God's decision. The person of good sincerity in life will be free from all forms of a stressful situation, anxiety, and life turmoil.

In simple words, all Sufi medical instruments mentioned above are categorized into three types such as Sufi medical treatments through Bayani tradition, Sufi treatment through the Irfani reasoning, and Sufi medical treatment through the Bil Kasbi tradition. Bayani's tradition is an Arabic method of thinking based on classical text (nash). Text has a strategic role and function to reduce all problems. Ratio and logical reasoning rely on the text (Al-Jabiri, 1991). The traditional distinctive features lie in the form of manifestation based on 'Kitab Kuning' (books written in Arabic and mostly printed yellow) the yellow books. Thus, Sufi medical treatment through Bayani tradition is oriented to the use of texts (texts), especially al-Qur ' an, hadiths, and works of the ulama salafus shaleh (old ulemas) produced in the Middle Ages, such as the so-called 'Kitab Kuning' (yellow books). In addition to Bayani, Irfani tradition also shows up. However, the method of sufi healing through Irfani tradition is based on Kasyf; the disclosure of God's reality secrets. Therefore, the knowledge of Irfani is based on spiritual ritual activities, such as heart purity (Al-Jabiri, 1991). With heart purity, God will surely bestow healing. The element of Irfani is based on inner light such as exercises for heart cleanliness to getting closed to God (mujahadah). Zikir (remembrance), fasting, praying, prayers, and repentance are some techniques applied in the element of Irfani. In simple words, Irfani tradition prioritizes mujahadah, tazkiya and nafs.

The tradition of Bil Kasbi, furthermore, is the result of experience and search for the experiment of the kiai physician concerned for patients' treatment. Data shows that Islamic therapists also use the method of Irfani prayer such as rukiyah, suwuk, salat, dzikir, water, tattoo, fasting, and so forth. It means that the tradition of bil kasbi is an implementation of the experimentation process and experience of the kiai physicians (Departemen Pendidikan, 1989).

\section{Sufi Healing Drive throughout East Java}

Islamic therapy clinics with commercial healing services mostly practiced in urban areas in East Java have similar healing methods to those traditional healing in pesantren. The traditional healing method normally practiced by kiai physicians comprises three elements such as Bayani, Irfani, and Bil Kasbi (Table 1).

el Harakah Jurnal Budaya Islam Vol. 22 No. 2 Tahun 2020 
Based on the observation data, healing treatments conducted by Islamic therapists adopts Sufi values which have been practiced in pesantren also known as Islamic therapeutic tradition of the pesantren community. Sufistic values are among others: the use of dzikir and prayer, rukyah, dzikr (remembrance), and routine taubah prayers. In addition, in dzikir and prayers recitation the therapists use Asma al-Husna (names of God), the use of some verses in the Holy Qur'an, as-Sunna (hadith), and some names of Angels, also holy water with asmak or rajah as the medium of healing. In general, people notice that the practices in Islamic therapy clinics throughout urban areas have similarities-through religious symbols-with those practiced by kiai physician in pesantrens. The use of Islamic labeling directly brings more value, especially for marketing purposes. Islamic branding can be a strategic and powerful magnet to attract people's interest and attention. To see the difference, table 2 displays methods of healing applied by kiai (ulema) physicians and therapists mostly used by healing clinics.

Table 1. Healing Model of Kiai tabib

\begin{tabular}{|c|c|c|c|}
\hline Element & Bayani & Irfani & Bil Kasbi \\
\hline $\begin{array}{l}\text { Source of } \\
\text { healing }\end{array}$ & $\begin{array}{l}\text { Texts in the Qur'an, as- } \\
\text { Sunnah (hadith), classical } \\
\text { books by Islamic tabib } \\
\text { (doctor), Asma al-Husna } \\
\text { (good names of God), } \\
\text { asma (names) of Malaikat } \\
\text { (angels), asma (names) } \\
\text { Nabi (prophets) }\end{array}$ & $\begin{array}{l}\text { Guidance, blessings } \\
\text { and mercy of God, } \\
\text { through inner } \\
\text { training process. } \\
\text { (Misticism, tasawuf) }\end{array}$ & $\begin{array}{l}\text { Search and } \\
\text { experience in } \\
\text { healing }\end{array}$ \\
\hline $\begin{array}{l}\text { Healing } \\
\text { Method }\end{array}$ & $\begin{array}{l}\text { Through rajah (call), } \\
\text { amulet, prayer, prayer, } \\
\text { and conduct }\end{array}$ & $\begin{array}{l}\text { Mujahadah (struggle), } \\
\text { Riyadlah (prayer), } \\
\text { zikir (recitative), } \\
\text { fasting, avoiding the } \\
\text { forbidden, prayer }\end{array}$ & $\begin{array}{l}\text { Physical and } \\
\text { psychological } \\
\text { therapy }\end{array}$ \\
\hline $\begin{array}{l}\text { Healing } \\
\text { Media }\end{array}$ & $\begin{array}{l}\text { Paper, water, ink, gold, } \\
\text { cloth, wood, callgraphy, } \\
\text { perfume, food }\end{array}$ & $\begin{array}{l}\text { Prayer, recitative, } \\
\text { water, food, anything, } \\
\text { animal }\end{array}$ & $\begin{array}{l}\text { herbs, } \\
\text { massage, } \\
\text { rukiyah, } \\
\text { hijama, } \\
\text { capsules }\end{array}$ \\
\hline
\end{tabular}

el Harakah Jurnal Budaya Islam Vol. 22 No. 2 Tahun 2020 
Table 2. Islamic Healing Therapy

\begin{tabular}{lll}
\hline Element & Gnosis/irfani & Adapted /bil kasbi \\
\hline Source of therapy & Self-adapted text of holy book & $\begin{array}{l}\text { Medical books, books of therapy, } \\
\text { coursebook }\end{array}$ \\
\hline Method of therapy & Prayer, recitative, & $\begin{array}{l}\text { Yoga, medical treatment, massage, } \\
\text { prana (breath, life-giving force) }\end{array}$ \\
\hline Media of therapy & water, herbs, toga mixture & $\begin{array}{l}\text { Herbs, medical tools, toga misture, } \\
\text { pharmaceutical medications }\end{array}$ \\
\hline
\end{tabular}

Nevertheless, many urban Islamic therapy clinics are in fact not fully able to imitate most activities of Sufi treatment frequently applied in pesantren. At least, three fundamental aspects can confirm points of differentiation between pesantren-based Sufi healing and the urban sufi healing.

First, it deals with the figure of kiai; in the traditional world of pesantren, kiai becomes the religious symbol full of greatness and honor which cannot be found in other social entities. Moreover, the presence of kiai has provided some features and advantages which are believed to bring the power of spirituality. Thus, kiai comes as a charismatic figure who supports sufi healing implemented in pesantren. This way, kiai himself provides ijazah in the process of sufi healing in pesantren. Also, kiai (ulema/guru) sometimes gives authority to santri (students/proteges) to recite certain prayers or dzikir taught through the yellow book (classic text). In addition, transfers of knowledge and expertise from kiai to the santri carried out through yellow book studies using Bandongan and Sorogan methods are also introduced. Moreover, this particular activity (transfer knowledge through the yellow books) are believed to be full of barokah (blessings/goodness) from the teacher (kiai) to santri (students).

Second, it deals with the presence of pesantren. Apart from the existence of kiai, traditional institutions like pesantren play a pivotal role in Sufi medical treatment, and this feature cannot easily be found and implemented in other institutions. Pesantren is the only institution full of religious spirituality in which Islamic values are developed and even transformed into social aspects of community life.

Sufi healing and medical treatments conducted in pesantren have great relevance in values. Sufi healing is a medical instrument based on religious values, spirituality, and self good deeds. Whereas, pesantren is a social entity in which religious studies are learned, discussed, and Islamic values are maintained and part of daily routines. Thus, like many medical treatments, in the name of 
Sufi healing, are practiced in most urban areas, it could probably be inspired by traditional medical pesantren treatment normally carried out in pesantren.

Third, it deals with the value of blessing. One of the pesantren's magical powers trusted by most people of the traditional community is barokah (blessing). The concept of barokah is believed to bring good fortune, to reject bad things, to provide physical and spiritual goodness. Barokah has a broad concept in which it can come from the pesantren, kiai, nyai (kiai's wife), or even asatidz (group of religious teachers) in the pesantren. Principally, the values of barokah are identical to all forms of kindness and blessing of life, leading people to a better life situation. In the context of Sufi healing, barokah is a special characteristic of Islamic therapy which is believed to bring healing, health and prevent people from a wide range of badness. Barokah is believed to be obtained through religious noble values (teachings) such as carrying out good deeds, virtues, upholding human rights, justice, and principles of humanism.

\section{Sufistic Values of Clinical Healing Practice throughout East Java}

In recent years, Sufi healing clinics have developed significantly throughout urban areas in East Java especially in big cities like Sidoarjo and Surabaya. The presence of sufi healing clinics in many areas of East Java seems to be the consequence of the growing trend of various medical treatments, also as an alternative effort to solve modern medical problems.

In its development, Sufi healing has profoundly transformed due to complex social changes in society. The more changes are induced, the social development has stronger implications towards community trust. Without adaptations, their existence as medical providers will likely be reduced significantly, or even considerably decline due to their inability to compete with other more modern clinics.

Based on data findings, many Sufi healing clinics introduce two popular strategies to maintain the existence of medical clinics in East Java. First, it deals with using medical methods and tools. The use of modern medical methods confirms that it also deals with modern medical treatments. For instance, during patient's medical records, they diagnose diseases just like modern medical professionals. The therapists also use medical terminologies such as names of viruses, bacteria, amoeba; names of diseases; cancer, obesity, miom, cyst, depression, et cetera, sometimes used as a method to analyze the physical condition of patients. They seemingly have similarities with the works 
of professional doctors with complete knowledge of human physiology and illnesses. This way, therapists will gain prospective patients' trust, confidence, and comfort. In addition, the use of medical terms will provide added value to development of patients' mindset that apart from skills and expertise needed in alternative healing (non-empirical) which commonly uses gnosis (mysticism) values and other sufistic treatments such as prayer, remembrance, tirakatan/ other ritual activities) in healing, the therapists also have sufficient expertise and knowledge of modern medical treatments.

In addition, other facts found during the observation are related to their ability to make herbal/drugs mixture. In addition to self-ability on concepts and medical terms, the therapists are equipped with skills to make their herbal medicines like a pharmacist normally does. Thus, herbal mixtures become such a therapist's breakthrough for medical treatment. In addition, permanent clients (patients) accept these particular herbal mixtures as they are free from chemical elements, and is believed to be good health.

However, though considered to be part of herbal treatment, the herbal mixture is not packed in the form of traditional herbal medicine, but a more modern forms such as capsules, tablets, and bottles of liquid drugs. According to the therapists, this is an effective strategy as people prefer herbal remedies to water, prayer, as mostly carried out by kiais in pesantren. Such a strategy survives and is frequently used by therapists in urban areas, even amid the growing development of modern health promotion by hospitals, physicians associations, and the government.

Second, it deals with psycho-sufistic treatment. According to the theory of psychology, the mindset of sick people is triggered by their perception or self-assessment of their health conditions. Thus, self-perspective and selfsuggestion can lead to reality; what is constructed in mind will likely occur in real life. Therefore, individuals are encouraged to build positive feelings within themselves and to get rid of negative thinking.

One's internal psychological factors trigger his/her health disorders and symptoms of a devastating illness. Thus, when one experiences health problems, his thoughts and feelings should get immediate treatment, not his/her physical condition. Competitions in life encourage people to initiate efforts to reach their goals so that their daily activities are full of turbulence of souls, emotions which eventually cause inner stress. The symptoms of inner pressures include insomnia, stress, loss of work motivation, sensitivity, depression, even potentially suicidal behavior.

el Harakah Jurnal Budaya Islam Vol. 22 No. 2 Tahun 2020 
The emergence of inner stress symptoms is due to no balance between physical (material) needs and mental needs (non-material), and spiritual emptiness occurs as the result of rapt attention on physical needs only. Troubling thoughts and feelings will likely lead to mental fatigue which will eventually affect physical health. Therapists notice that problems of public health bring business opportunities. This encourages them to run alternative healing services especially to assist the underprivileged. Therapists generally assist with the process of healing and soul purification such as massage, relaxation, steam baths, gymnastics, and meditation programs for physical fitness especially to combat physical fatigue caused by stress.

Whereas, the soul purification program deals with a wide range of prayer activities, dhikir (remembrance), and focused prayer practice giving an impact on healing any kind of ailments. Furthermore, in their development, they also offer umrah (Mecca and Medina pilgrimage) and tours program specifically designed to improve one's spiritual experience, which in turn has an impact on one's health, career, and any achievements. In this case, people will be easily attracted by the healing programs through advertisements such as electronic media (TV, radio, internet), print media, newspapers, brochures, et cetera. The therapists make the most use of psychological aspects of prospective patients such as stress, anxiety which require immediate and inexpensive solutions; through soul recovery and purification programs, for instance. The programs deal with the use of Sufistic values useful for the patients who are mostly muslims that they certainly feel comfortable and accept the healing methods. Hence, plasebo effects occur in which therapists meet the patients' needs especially the ones considered to be able to provide solutions to their problems. Furthermore, therapists feel confident in their ability to cure patients of their diseases.

\section{Religious Reification and Sufi Healing Phenomenon in East Java}

The concept of religious reification was firstly introduced by George Luckas (1885-1971), a neo Marxian thinker who frequently criticized theory of capitalism by Karl Marx. Luckas claimed that capitalization in the social system of contemporary society was not about society to obey system mastery and be merely part of economic production (dialectical materialism) (Ritzer, 2010). Furthermore, Luckas suggested that increasingly complex development of society and growing violence of social change made capital practices deal with more complex forms of commodification, and it can even become social 
structures which collide with the reality of life; in the form of norms, economic law, tradition, culture, and even religion.

The term religious commodification with George Luckas's definition of reification implies social phenomena in which religion is modified for the sake of profits. Religion with its 'sacred reality' is underestimated for the sake of personal or group interest to meet their economic needs. Religion experiences the process of capitalization; the commodity for profit. This is due to its 'selling points' to influence the wider community, especially those with normative and textual mindsets. Thus, Karl Marx's thesis of capitalism confirmed that religion can even hypnotize society. Through the use of religious labeling, people's subjective perception can be deceived, rational and critical thinking becomes blunt.

Nevertheless, to the practice of Sufi healing throughout some urban areas in East Java, Islamic therapy clinics that provide true Sufistic-Islamic practices are hard to find. It indicated clear evidence of the religious capitalization phenomenon through Sufi medical instruments. Capitalization refers to the profit-oriented behavior of contemporary society. Facts found during the observations indicated that most Islamic therapy clinics in urban areas exist to adapt to the development of modern medical treatments. Economic considerations become the strongest reason why treatment with Islamic labels has currently developed rapidly. These particular therapists are well-informed that people of modern globalization appear more competitive so that the needs for alternative treatments are growing. Therefore, medical clinics with the use of Sufistic-Islamic symbols provide powerful and strategic ways to attract public attention.

Hence, therapists also play a pivotal role in helping people with their physical problems as well as the role of medical professionals. For this reason, therapists attempt to advertise their healing activities with Islamic values through some media such as televisions and newspapers. The basic principle of therapeutic practices is to develop religious symbols as well as the commercialization of religious values.

Symbolic religious forms displayed in the activities of therapists include the use of Islamic teachings implemented in the healing process such as prayer, rukyah, and dzikir. Even, some calligraphies or photos of Sufi figures-considered to have magical power-are sometimes attached to the walls of medical practices to attract prospective patients. Yet, In the end, it is not on a missionary and pious charity to prioritize as conducted by kiai when healing patients, but 
religion is taken advantage of to fulfill the therapist's achievements and needs of life. Such a perspective is the manifestation of religious commodification. Religion is no longer appears in its nature, yet it has become part of a social commodity. Religion is labeled undercapitalization to strengthen the economic bargaining position. Religion contains noble values, virtues, happiness in the hereafter, as well as values that influence the people's subjective consciousness. As Michel Foucault suggested that religion is the only institution that produces religious linguistics a discourse; normative and disciplinary power to produce identity and to facilitate compliance and obedience (Foucault, 1975).

The capitalization in the global era is no longer driven through economic institutions, it can also be dealt with elements of society's systems and structures including religion, education, culture, et cetera. In the context of Sufi Healing, religious capitalization, through Luckas' reification perspective, implies the use of religious elements especially those related to religious rituals and practices in addition to Islamic labels. Religious rituals are mostly represented in the form of remembrance activities (dzikr), prayer, or fasting. Whereas, practices which focus more on recital certain books are believed to bring goodness to heal patients.

Various methods of Sufi healing also have implications for its sources and funding. Bayani, Irfani, and Bil Kasbi have their perspective and work ethic. In the healing process Bayani, for instance, refers more to Islamic texts taken from the holy Qur'an, as-Sunnah, the classic book of Islamic physicians, Asma al-Husna (names of God), names of angels, names of Prophets, et cetera. Whereas concerning ways of healing, it focuses on Rajah water, amulet, suwuk, prayer ijazah, and some other practices in which paper, water, gold ink, cloth, wood, calligraphy, perfume, and food are used as a healing medium.

Irfani works in different ways though. It relies more on the power of guidance, grace and the help of God carried out through the mind training process (mysticism, Sufism). Exercise of mind requires self-purity, the purity of soul from evils, and all kinds of negative attributes. Rather, relying on spiritual strength and self-goodness. The closer one is to God the creator, the more peaceful his/her mind and soul will be, the more stable his/her mind is. Irfani healing method uses the principles of mujahadah, riyadlah, remembrance, fasting, tirakat, prayer, and other religious rituals. Prayers, dzikir, water, and food are some of media normally used in Irfani-based Sufi healing.

In contrast to Bayani and Irfani, Bil Kasbi sufistic method of treatment emphasizes search and experience. However, Bil Kasbi is not based on modern 
methods. Bil Kasbi focuses on searching and experiencing through traditional methods, such as physical therapy and psychological therapy using herbal medicine, massage, rukiyah, hijama, and capsules.

Hence, based on those facts, the practice of religious capitalization and reification in Sufi healing throughout East Java is part of religious elements. Religion is introduced to the public through Sufi healing and when people understand this phenomenon, they rely on medical clinics. However, this fact reveals that religion has lost its true meaning as economic distortion occurs and profits are brought in.

\section{Conclusions}

Religious capitalism is the social phenomenon emerging as the result of contemporary community development one of which is religious symbolism religious through reification and profit-oriented social activities. For instance, sufi healing comes with symbolized aspects of economic background. Sufi healing appears as a healing instrument now popularly implemented in several urban areas. The healing techniques are based on religious and spiritual power firstly came from pesantrens (Islamic boarding schools) in which most Islamic values were taught and ritual activities were carried out.

Nevertheless, during its development, sufi healing has been in the spotlight. People consider sufi healing as an alternatively more optimal solution for a health problem than common medical healing process. Therefore, sufi healing attracts public attention, and clinics offering such a healing method spread across several areas most of which are urban environments such as Surabaya and its immediate vicinity.

In general, three models of sufi healing are mostly implemented in some urban areas like Surabaya namely Bayani, Irfani, dan Bil Kasbi with Irfani as the most applied method normally through praying, zikir (recitative), and prayers. In addition, the methods implemented during the healing are medical and psycho-sufistic processes to boost patient's confidence. The medical process merely refers to the use of modern medical terminologies during the healing process. Whereas, sufistic implementation refers to religious and spiritual aspects such as healing resources, healing methods, and healing media. These three aspects convinced that most modern sufi healings are parts of profitoriented activities. Thus, they are parts of religious capitalism as dealing with clinical healing in the form of sufi healing with economic background. 


\section{References}

Ahnan, M. n.d..Kamus Arab-Indonesia. Gresik: Bintang Pelajar.

Al-Aziz, M. S. 1998. Risalah Memahami Ilmu Tashawwuf. Surabaya: Terbit Terang.

Al-Ghazali, I. n.d..Ihya' Ulumuddin: Menuju Filsafat Ilmu dan Kesucian Hati Insan Ihsan Bandung: Bintan.

Al-Ghazali, I. 1995. Imam. Muhtasar Ihya Ulumuddin, Terj. Zaid Husein al-Hamid. Jakarta: Pustaka Aman.

Al-Jabiri. 1991. Bunyah al-Aql al-Arabi. Beirut: al-Markaz al-Tsaqafi al-Arabi.

As-Sarraj, A. N., Terj. Wasmukan dan Samson Rahman, 2002. Al-Luma': rujukan lengkap ilmu tasawuf. Risalah Gusti.

Burij, A.-Q. al-N. n.d.. Ar-Risalah al-Qusyairiah fi Ilmi at-Tasawuf. Dar al-Khairi

Departemen Pendidikan. 1989. Kamus Besar Bahasa Indonesia. Jakarta: Balai Pustaka.

Djaelani, A. Q. 1996. Koreksi Terhadap ajaran tasawuf. Gema Insani Press.

Foucault, M. 1975. The Archeology of Knowledge and the Doscourses on Language. The Harvester Press.

Hermansen, M. 2005. Dimensions of Islamic Religious Healing in America. Religion and healing in America, 407-422.

Isa, A. Q. 2005. Hakikat Tasawuf, transl. Khairul Amru. Jakarta: Qisthi Press.

Jamil, M. 2004. Cakrawala tasawuf: sejarah, pemikiran $\mathcal{E}$ kontekstualitas. Gaung Persada Press.

Mitha, K. 2019. Sufism and healing. Journal of Spirituality in Mental Health, 21(3), 194-205. https://doi.org/10.1080/19349637.2018.1464423

Noorhayati, M. 2016. Konsep Qonaah dalam Mewujudkan Keluarga Sakinah Mawaddah dan Rahmah. Jurnal Bimbingan Konseling Islam, 7(2), 59-76.

O'riordan, R. N. L. 2002. Seni Penyembuhan Alami: Rahasia Penyembuhan Melalui Energi Ilahi, diterjemahkan oleh Sulaiman AlKumaiyi dari judul asli The Art of Sufi Healing. Gugus Press. 
Pasiak, H. T. 2007. Brain management for self-improvement. Mizan Pustaka.

Poerwadarminta, W. J. S. 1976. Kamus Umum Bahasa Indonesia, 5th ed. Balai Pustaka.

Pradityas, Y. B., Hanafi, I., \& Zaduqisti, E. 2015. Maqamat Tasawuf dan Terapi Kesehatan Mental (Studi Pemikiran Amin Syukur). RELIGIA, 187-206.

Rabbani, W.B. Wirasubrata 2004. Sufime Islam. Sahara Publishers.

Rubaidi, R. 2019. Java Islam: Relationship of Javanese culture and Islamic mysticism in the post-colonial study perspective. El Harakah, 21(1), 19-35.

Ritzer, G. 2010. Teori Sosiologi, transl. Nurhadi. Kreasi Wacana.

Sentanu, E. 2008. The Science EF Miracle of Zona Ikhlas. Elex Media Komputindo.

Sha, Z. G. n.d.. The Miracle of Soul: Rahasia Abadi Penyembuhan, Peremajaan diri. Yureka.

Syukur, A. 2012. Sufi Healing Terapi dengan Metode Tasawuf. Erlangga.

Thusi, K. N. A. 2003. Menyucikan Hati Menyempurnakan Jiwa. Pustaka Zahra.

Trimingham, J. S. 1998. The sufi orders in Islam. Oxford University Press.

Wilcox, L. 2007. Psychosufi Terapi Psikologi Sufitik Pemberdayaan Diri. Pustaka Cendekiamuda.

el Harakah Jurnal Budaya Islam Vol. 22 No. 2 Tahun 2020 
